BLACK, M., 1934. In A Synopsis of the Jurassic Rocks of Yorkshire. III. The Middle Jurassic Rocks. Proc. Geol. Assoc., xlv, 261.

Fox-STRANGWAYS, C. The Jurassic Rocks of Britain: Vol. I-Yorkshire. Mem. Geol. Surv.

Kendall, P. F., and WroOt, W. E., 1924. The Geology of Yorkshire. Leeds.

MorrIs, J., 1853. On Some Sections in the Oolitic district of Lincolnshire. Quart. Journ. Geol. Soc, ix, 317.

Simpson, M., 1868. A Guide to the Geology of the Yorkshire Coast (Fourth Edition), pp. 36-40, Whitby.

\title{
CORRESPONDENCE
}

\section{INDEX FORAMINIFERA OF THE CHALK}

SIR,-Considerable research has been undertaken during the last few years, particularly by petroleum geologists, to establish zonal indices among the foraminifera of the Chalk of England, Sweden, and North Germany. The English Chalk has been studied by E. Williams-Mitchell and the Swedish by Dr. F. Brotzen, while at least six workers, Altaner, Bettenstaedt, Hiltermann, Olbertz, Wedekind, and Wicher, have made valuable contributions towards this subject in North Germany. The results of all these studies are now available in published form.

The Anglo-Iranian Oil Company, London, have received from Dr. O. Heermann, of the Deutsche Vacuum Oil Company, the gift of a topotype set of some of the material from borings at Cuxhaven and Siegfried, consisting of named and mounted index species of each zone from the Turonian to the Maestrichtian.

In order that this material may be available to students the Company have decided to present it to the British Museum (Natural History), where Mr. C. D. Ovey is gradually building up a collection of Mesozoic and Tertiary material, his ideal being to accumulate as complete a stratigraphical sequence as possible, solely for the purpose of studying the microfauna zonally and biologically. Both from this aspect and from the fact that many important type collections, including F. Chapman's and Williams-Mitchell's Chalk specimens are preserved there, the Cuxhaven and Siegfried material is obviously an enhancement.

\section{Anglo-Iranian OIl Company.} 10 th November, 1948.

\section{A. G. Davis.}

\section{THE TERM "MAGMA-TYPE"}

SIR,-In their recent paper " On Magma-Types and their Nomenclature" (Geol. Mag., 1948, p. 349) Mr. M. K. and Dr. A. K. Wells seem to be straining at a couple of inoffensive gnats whilst swallowing with relish a particularly monstrous camel. I am grateful to my two friends for providing me with a suitable opportunity for making a protest-long overdue-against the use and misuse of the term "magma-type". Far too many petrologists have fallen into the habit of speaking of "magma-types ", or even of " magmas", when they simply mean rocks. Scientific jargon, appropriate to the circles in which it is understood, cannot be altogether avoided, but this particular example is so definitely unscientific and mischievous that it has become a positive danger.

Defined objectively, a so-called " magma-type" is the mean of a number of chemical analyses of rocks (of igneous or supposedly igneous origin) so similar in composition that the deviation of each constituent from its mean 